\title{
Two new species of Zygophyllum (Zygophyllaceae) from the Western Cape, South Africa
}

\author{
L. VAN ZYL (née HUGO)* and E.M. MARAIS*
}

Keywords: new species, South Africa, Western Cape, Zygophyllaceae, Zygophyllum

ABSTRACT

Two new species of Zygophyllum L. from the Western Cape are described, namely, Z. fuscatum Van Zyl from the coastline between Betty's Bay and De Hoop Nature Reserve and Z. botulifolium Van Zyl from the Tanqua Karoo.

\section{INTRODUCTION}

Sonder (1860) in Flora capensis, recognized 25 species in his revision of the genus Zygophyllum in southern Africa. Van Huyssteen (1937) added a few more new species. Since then many more new taxa from all over the distribution range of the genus have come to light and in this paper two new species are dealt with. Both belong to the subgenus Zygophyllotypus Huyst., section Capensia Engl. which is by far the largest section of the southern African species of Zygophyllum.

Young stems of species in section Capensia are mostly not round in cross section but flat on one side and they nearly always display lateral ridges containing vascular bundles which presumably serve the stipules. The flat area with lateral ridges occurs along the whole length of the internode. This side of the young stem could be described as nearest to the central axis of the shrub, and therefore the descriptive term, ventral, is used with this situation in mind. Members of another section of Zygophyllum, namely section Alata, often display a distinct ventral groove along the whole length of the internode. Figure 1.

Zygophyllum fuscatum $\mathrm{Van} \mathrm{Zy}$, sp. nov., (§ $\mathrm{Ca}$ pensia), Z. fulvo L. affinis sed frutex erectus ramulis dense foliaceis secundis, fructibus angulatis et costatis. Figura 2.

Frutex erectus multicaulis. Ramuli dense foliacei, secundi, internodia ventraliter complanata, costis lateralibus angustis in lobum distinctum acutum distalem terminantibus. Folia opposita, subsessilia, bifoliolata, foliola elliptica vel obovata, in sicco nigrescentia. Pedicelli brevissimi, 1-2 mm longi; petala flavissima. Squamae staminum simplices, oblongatae, margine fimbriato, longitudine $1 / 3$ filamentorum partes aequantes. Ovarium 5 angulatum. Fructus capsula loculicida oblonga, 5-angulata et 5-costata. Semen arillo albo, testa madida mucum procreans.

TYPE.-Western Cape, 3419 (Caledon): coastal dunes between Kleinbaai and Danger Point, $(-\mathrm{CB})$, May 1992, Van Zyl 4293 (NBG, holo.; B, PRE, S).

* Department of Botany, University of Stellenbosch, Private Bag X1, Matieland, 7602 Stellenbosch.

MS, received: 1997-01-02.
Erect, multistemmed, branched, glabrous shrub up to $1.0 \mathrm{~m}$ high and $1.5 \mathrm{~m}$ in diameter. Stems: old stems leafless, dark grey, up to $20 \mathrm{~mm}$ thick; young branches green, densely leafy, secund, internodes ventrally flattened with narrow lateral ridges, each ending in a distinct, acute, distal lobe (Figure 2D). Leaves opposite, subsessile, bifoliolate, khaki or yellow green, when dried changing colour to dark brown or nearly black; leaflets articulate, elliptic to obovate, not succulent, 12-16 $\times 2-5$ $\mathrm{mm}$, apex rounded or acuminate, with an apiculum, base cuneate; stipules interpetiolar, membranous, caducous, subrotund, sometimes slightly notched, $0.5-1.5 \times 1-2$ $\mathrm{mm}$. Flowers solitary or seldom two together, axillary. Pedicel 1-2 mm long. Sepals 5, ovate to elliptic, attenuate, 6-8 $\times$ 3-4 mm. Petals 5, patent, subrotund or elliptic, $10-14 \times 5-7 \mathrm{~mm}$, apex round or acuminate, base with a short claw, deep yellow and variously marked at base with red or brown, or without any markings. Nectar disc fleshy, papillose, 10-angled. Stamens 10; filaments terete, 5.5-8.0 mm long; staminal scales 10, simple, oblong, margins unevenly lacerate, $2-3 \times 1.0-1.5 \mathrm{~mm}, \pm$ one third as long as filament. Ovary 5-angled and 5-locular; style terete; stigma simple. Fruit an oblong, 5-angular and 5-ribbed, few-seeded, loculicidal capsule, 12-14 $\times 11-12 \mathrm{~mm}$. Seed oblong, up to 3 per locule, $4 \times 2 \mathrm{~mm}$, dark brown with white aril, testa producing mucilage when wet.

\section{Diagnostic characters}

Zygophyllum fuscatum resembles Z. fulvum L. and Z. flexuosum Eckl. \& Zeyh. but is readily distinguished from the former by its erect, shrubby habit, densely leafy,

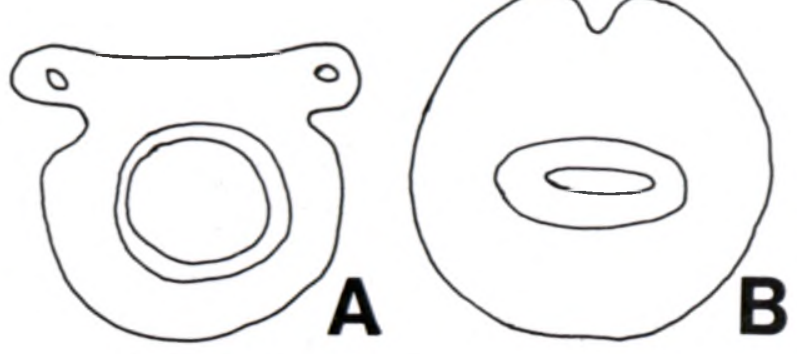

FIGURE 1.-Section through intemode. A, Z. fuscatum, Van Zyl 4293 (section Capensia); B, Z. suffruticosum Schinz, Van Zyl 3809 (section Alata). 


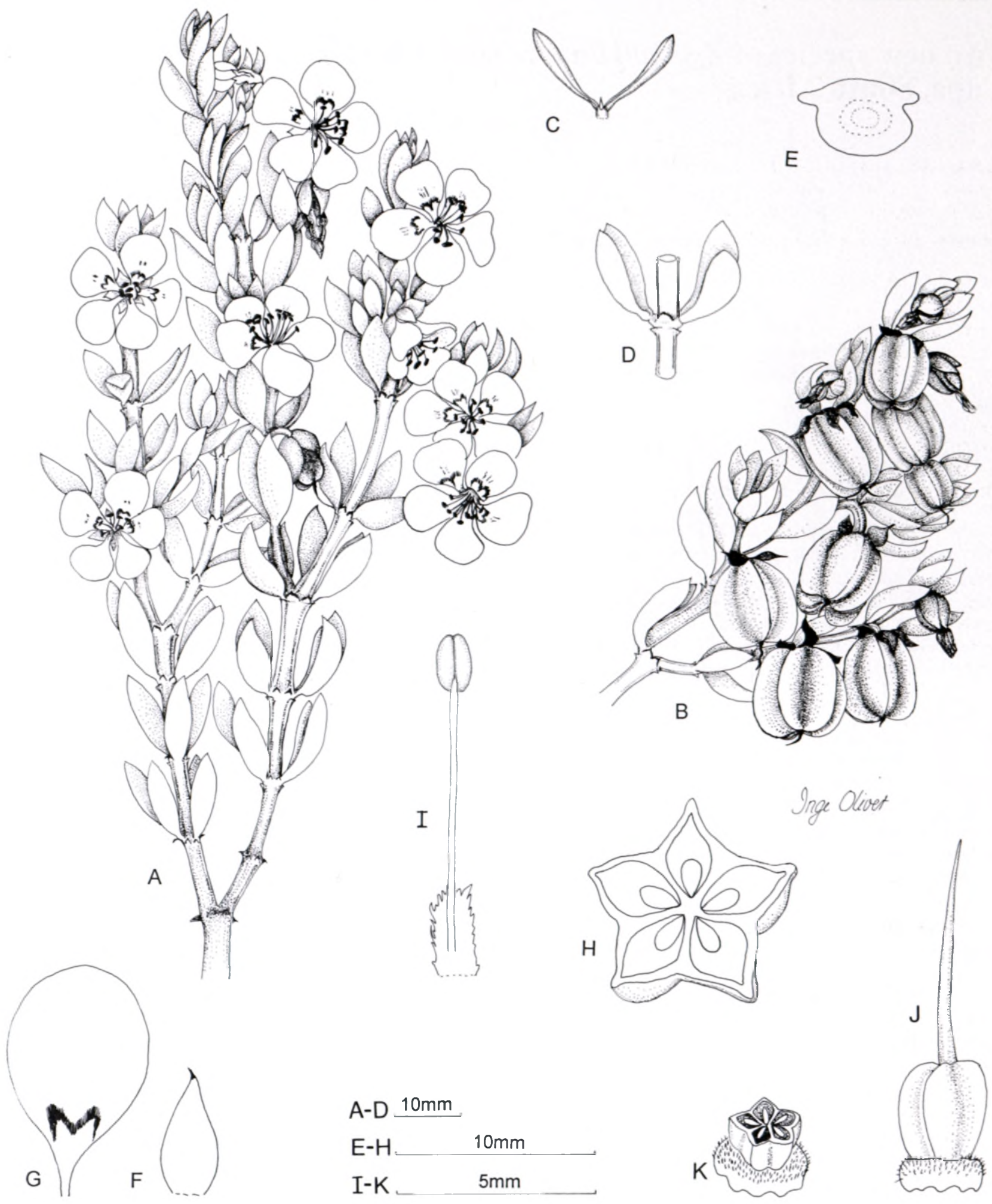

FIGURE 2.-Zygophyllum fuscatum, Van Zyl 4293, holotype. A, flowering branch; B, fruiting branch; C, sideview of leaflets; D, leaflet arrangement, lateral ridges and distal lobe on internode; E, section of internode; F, sepal; G, petal; H, section of capsule; I, stamen with scale; J, ovary; K, section of ovary.

secund young branches which turn dark brown or nearly black when dried, (hence the specific epithet which is Latin for brown tinged with black), also by the absence of scabrous leaf margins, which are characteristic of $Z$. fulvum. The internodes of young stems are always flat on the ventral side and have narrow, lateral ridges ending in distinct, acute distal lobes. These ridges are present in all three taxa mentioned above but only $Z$. fuscatum displays these distinctive lobes. The very short pedicels
(1-2 mm) of $Z$. fuscatum also differ from those of $Z$. fulvum and $Z$. flexuosum which vary from $9-20 \mathrm{~mm}$. The oblong, 5-angled and 5-ribbed, loculicidal capsules of $Z$. fuscatum, with up to three seeds per locule, differ markedly from those of $Z$. fulvum which are subrotund, without angles, showing only faint remains of sutures, and those of $Z$. flexuosum, distinguished by being wider than long, and containing only one, extremely sticky seed per locule. 


\section{Distribution and habitat}

Z fuscatum is found in a narrow strip along the southern Western Cape coastline, from Betty's Bay in the west to De Hoop Nature Reserve in the east, mostly in close proximity to the sea, from sea level to about $300 \mathrm{~m}$ altitude (Figure 3 ). The vegetation is classified as Limestone Fynbos by Rebelo (1996) and is restricted to calcareous, neutral to alkaline, shallow sands overlying limestone and associated calcretes of the Bredasdorp Formation. The area falls within the winter and autumn-spring rainfall area, with rainfall varying from 350 to $600 \mathrm{~mm}$ per year and with average daily temperatures of $17^{\circ} \mathrm{C}$. Also found in this area are two other Zygophyllum species, namely Z. fulvum L. and Z. flexuosum Eckl. \& Zeyh. Z. fuscatum thrives in direct sunlight and is often seen as a pioneer in disturbed areas along roadsides. Populations of many scattered individuals exist, including seedlings and young plants. Z. fuscatum is fairly common where found and under no threat of extinction. Flowering occurs from May to August and fruits are shed a month or two later.

\section{Specimens examined}

WESTERN CAPE - 3418 (Simonstown): Holbaai Peninsula, E of Hangklip, (-BD), June, Rourke 423 (NBG); E of Blesberg, Hangklip. (-BD), Sept., Boucher 684 (NBG): Betty's Bay, (-BD), June, Hall 1738 (NBG). 3419 (Caledon): Danger Point, Caledon, (-CB), June, Lewis 4025 (SAM); June, Marlin 338 (NBG); near Die Kelders, (-CB), May, Van Zyl 4294 (NBG); coastal dunes, W of Kleinbaai, (-CB), May, Van Zyl 4292 (NBG); coastal dunes between Kleinbaai and Danger Point, (-CB), May, Van Zy/ 4293 (B, NBG, PRE, S); coastal fynbos at Buffelsjag. Quoin Point, (-DC), July, Van der Zeyde 54/83 (NBG); near Ratel River mouth, (-DC), June, $O^{\prime}$ Callagan, Van Wh \& Fellingham 471 (NBG); near Quoin Point, Buffelsjag, (-DC), May, Van Zyl 4290 (NBG). 3420 (Bredasdorp): Dronkvlei flats. De Hoop Nature Reserve. (-AD), June, Burgers 1854 (NBG); near Amiston, (-CA), July, Marsh 1452 (PRE, NBG); coastal dunes near Bredasdorp. (-CA), Aug., Van Breda 814 (PRE).

Zygophyllum botulifolium Van Zyl, sp. nov., ( $\$$ Capensia), frutex erectus a speciebus aliis sectionis foliis cylindricis, succulentibus distinguitur. Figura 4.

Frutex erectus, multicaulis. Internodia ventraliter complanata, leviter costata. Folia opposita, sessilia, bifoliolata; foliola cylindrica, succulenta. Petala sulphurea vel aurea. Squamae staminum simplices, ellipticae, margine fimbriato, filamentis dimidia parte breviores. Ovarium 5-angulatum. Fructus capsula loculicida, subrotunda, 5-angulata et 5-costata. Semen arillo albo, testa madida mucum procreans.

TYPE.-Western Cape, 3319 (Worcester): Doornrivier crossing between Ceres and Sutherland, (-BB), September 1989, Van Zyl 3935 (NBG, holo.; B, BOL, PRE, S, WIND).

Erect, compact, branched, woody shrub, up to $0.6 \mathrm{~m}$ high and $0.6 \mathrm{~m}$ in diameter. Stems: old stems woody, dark grey, resprouting at nodes, young branches green, ventrally flattened, with weakly developed lateral ridges on internodes. Leaves opposite, sessile, bifoliolate, dark green, sometimes with brown tints; leaflets articulate, cylindrical, succulent, $7-13 \times 2-3 \mathrm{~mm}$, apex and base rounded; stipules interpetiolar, membranous, caducous, triangular, 1.0-1.5 mm. Flowers solitary, axillary. Pedicel
7-10 mm long. Sepals 5, ovate, 7-8 $\times 3 \mathrm{~mm}$, light green. Petals 5, patent, elliptic to subrotund, 9-11 $\times 4-5 \mathrm{~mm}$. with short claws, sulphur-yellow to rich golden yellow, variously marked in red, brown or khaki at base. Nectar disc fleshy, papillose, 10-angled. Stamens 10; filaments terete, 5-7 mm long; staminal scales simple, elliptic, 3-4 $\times 1.0-1.5 \mathrm{~mm}$, more or less half as long as filament, margins long fimbriate. Ovary oblong, 5-angled; style terete; stigma simple. Fruit a subrotund, 5-angled and 5-ribbed, loculicidal, few-seeded capsule, $11 \times 10 \mathrm{~mm}$. Seed oblong, 4.0-2.5 mm, dark brown, white aril present, testa granular, producing mucilage when wet.

\section{Diagnostic characters}

Zygophyllum botulifolium is distinguished by its very succulent, cylindrical leaflets (hence the specific epithet which is Latin for sausage-leaved), a feature in which it resembles the dwarf shrubs of the Mesembryanthemaceae amongst which it is always found. $Z$. simplex also has succulent but not cylindrical leaves and these two species should not be confused with one another because of their very different habit: $Z$. simplex is a prostrate annual whereas $Z$. botulifolium is an erect, woody shrub. Although the young stems of $Z$. botulifolium are flat on the ventral side, the lateral ridges on the internodes are poorly developed compared to other members of section Capensia. It is further distinguished by the staminal scales with long, fimbriate margins and by the subrotund, 5-angled and 5-ribbed capsule. This species has no close affinities with other members of the section $\mathrm{Ca}$ pensia.

\section{Distribution and habitat}

Z. botulifolium is restricted to the southern part of the Tanqua Karoo and, according to distribution records, is found together with only one other Zygophyllum species, namely Z retrofractum Thunb. which belongs to subgenus Agrophyllum Huysst. The vegetation of the Tanqua Karoo is classified as Lowland Succulent Karoo by Hoffman (1996), or Tanqua Karoo by Acocks (1988), and contains a high succulent plant species diversity. According to Acocks (1988) the valleys of the Tanqua

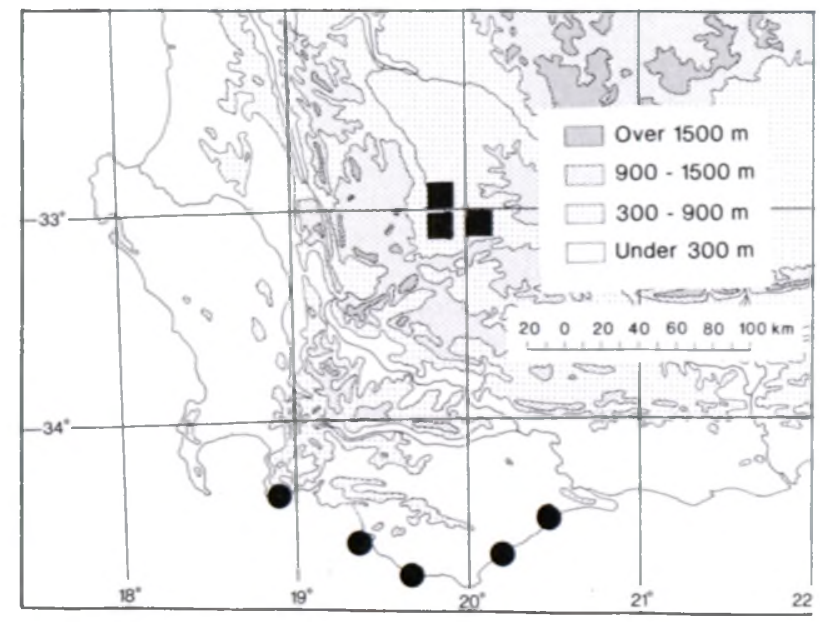

FIGURE 3.-Distribution of Zygophyllum fuscatum Van Zyl, $\bullet: Z$ botulifolium Van Zyl, 


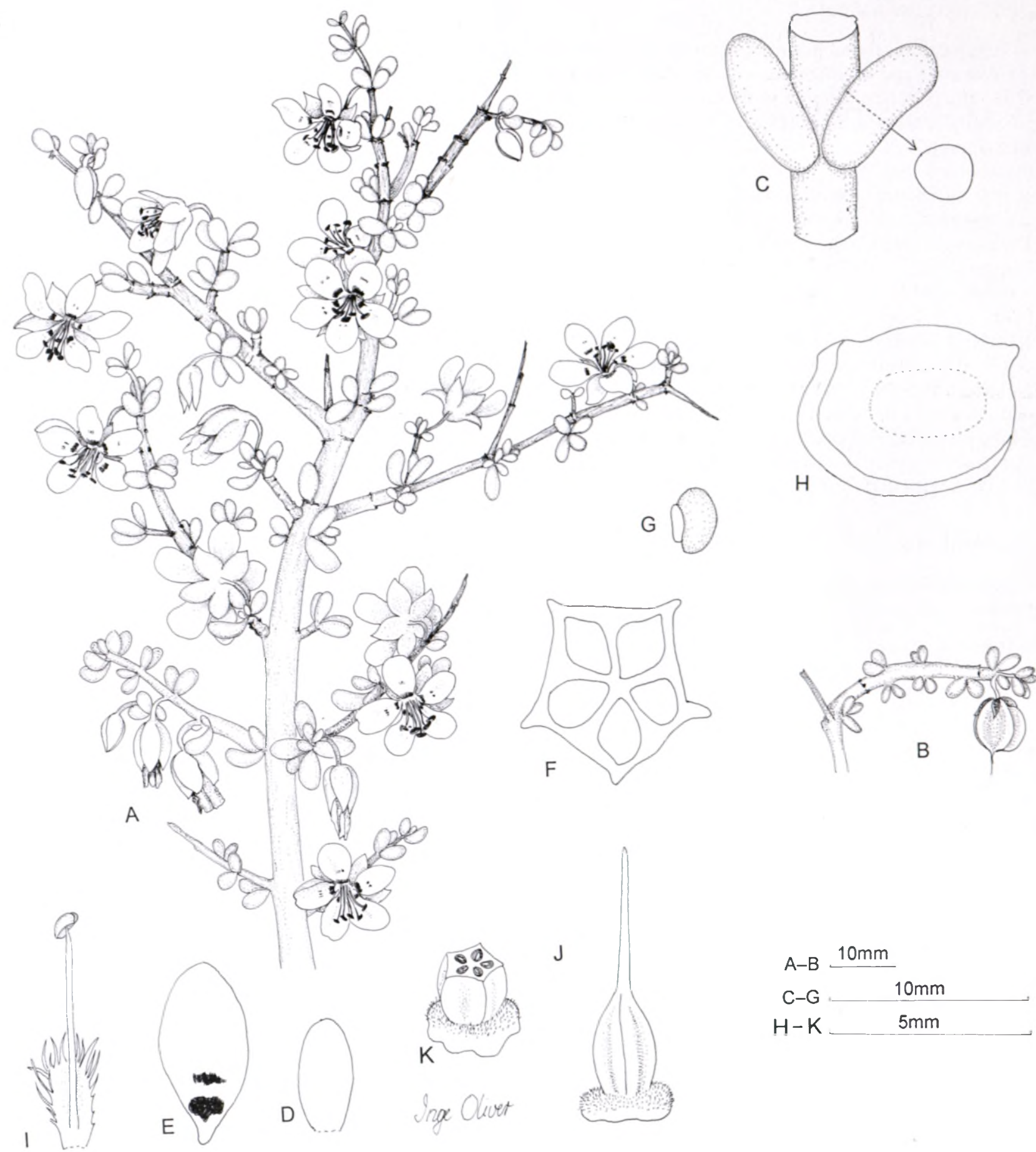

FIGURE 4.-Zygophyllum botulifolium, Van Zyl 3935, holotype. A, flowering branch; B, fruiting branch; C, leaflets with cross section; D, sepal; E, petal; F, section of capsule; $G$, seed; H, section of internode; I, stamen with scale; J, ovary; K, section through ovary.

and Doorn Rivers are flat country, mostly 300-450 m above sea level, and receive less than $150 \mathrm{~mm}$ rain per annum, falling mostly in winter. The lower parts of these valleys can be considered as being almost total desert. It is quite normal to find very few flowers and even fewer fruits on shrublets of $Z$. botulifolium. Over a period of nearly 10 years, during which collections were made, this was mostly the case with the exception of one good rainy season when plants were found covered in flowers and fruits. Populations of $Z$. botulifolium consist of a few dozen scattered plants which are usually found near dry stream beds, mostly tributaries of the Doorn River. In a sterile state this species may be mistaken for a shrublet of the Mesembryanthemaceae. Most plants are heavily grazed and have a gnarled, pruned appearance. The fact that plants are edible and that the whole of the distribution range falls within sheep farming area, could account for the near absence of seedlings or young plants. Because of the small size of populations and grazing pressure, this species could be considered as vulnerable. Flowering takes place from July to August.

\section{Specimens examined}

WESTERN CAPE. - 3219 (Wuppertal): Grootrivierloop at Soutpanskoppies, Ceres Karoo, (-DD), July, Van Zyl 4200 (NBG, PRE) 3319 (Worcester): Doornrivier crossing between Ceres and Sutherland, (-BB), Sept., Van Zyl 3935 (B, BOL, NBG, PRE, S, WIND); Doornrivier crossing between Ceres and Sutherland, (-BB), 
July, Van Zyl 4026 (NBG, PRE); near Doomrivier, Ceres, (-BB), Sept., Van Zyl 3742 (NBG. PRE); Doornrivier crossing between Ceres and Sutherland, (-BB), Sept., Van Zyl 4237 (NBG, PRE); between Inverdoorn and Tweeriviere, Ceres Karoo, (-BB), Aug., Van Zyl 4238 (NBG). 3320 (Montagu): between Tootberg and Perdekraal, (-AA), Nov., Van Zyl $4 / 53$ (NBG. PRE)

\section{ACKNOWLEDGEMENTS}

We are most grateful to Mrs Inge Oliver for the care with which she prepared the line drawings and to $\mathrm{Mr}$ E.G.H. Oliver for the Latin translations.

\section{REFERENCES}

ACOCKS, J.P.H. 1988. Veld types of South Africa, 3rd edn. Memoirs of the Botanical Survey of South Africa No. 57: 1-146.

HOFFMAN, T. 1996. Lowland Succulent Karoo. In A.B. Low, \& A.G Rebelo, Vegetation of South Africa, Lesotho and Swaziland. Dept Environmental Affairs \& Tourism, Pretoria

REBELO, A.G. 1996. Limestone Fynbos. In A.B. Low, \& A.G. Rebelo. Vegetation of South Africa, Lesotho and Swaziland. Dept Environmental Affairs \& Tourism. Pretoria.

SONDER, O.W. 1860. Zygophyllaceae. In W.H Harvey \& O.W Sonder, Flora capensis 1: 355-365. Reeve, Ashford, Kent

VAN HUYSSTEEN, D.C. 1937. Morphologisch-systematische Siudien über die Gattung Zygophyllum mit besonderer Berücksichrigung der afrikanischen Arten. Inaugural-Dissertation der Mathematisch-Naturwissenschaftlichen Fakultät der Friedrich Wilhelms-Universität zu Berlin. 